\title{
Perspectives of Fishers on Impact of Pandemic Covid'19 on Fisheries Business Operating in Coastal Maharashtra
}

\author{
Bhavesh B. Vaity' and K. Y. Shinde ${ }^{2}$ \\ ${ }^{1}$ Marketing, PTVA's Institute of Management, University of Mumbai, India \\ ${ }^{2}$ Sant Gadge Maharaj College of Commerce. Et Economics, University of Mumbai, India
}

\begin{abstract}
COVID'19 Pandemic i.e. Novel Coronavirus Global Epidemic resulted in nearly shut down of overall business fraternity in both organised and unorganised segments globally. As there was no immediate relief for the illness governments all across globe had no other options than putting restrictions on movement of people which gradually forced for complete lockdown in high density regions especially the urban and semi-urban regions. As the business vis-à-vis logistics is symbiotic for remote villages / towns on urban infrastructure for all allied industries it also brought gradual business shutdown in villages and town. Furthermore certain cases were found in secluded areas as well henceWorld Health Organisation (WHO)gave guidelines to governments to take immediate steps to stop the outbreak, hence Indian Government called for complete Lockdown of the nation. India being an agrarian economy wherein majority business set-ups are still under private unorganised sector, The Fishery sector which comprises of widely artisanal and small scale occupational aboriginal communities those are furthermore disorganised. The Lockdown imposed had stopped all the activities of Fishery related business. The impact of same was on income and overall livelihood of fishers as well as fishing allied ecosystem. Once the government started gradually opening up the markets and activities the business seems to be getting back to normal. The study directed towards the lockdown and post lockdown business of Fishery Industry that is severely impacted due to Pandemic.
\end{abstract}

KEY WORDS: COVID-19PANDEMIC, FISHERIES; COASTAL COMMUNITIES; INDIAN FISHERIES, INCOME, LIVELYHOOD, COASTAL MAHARASHTRA.

\section{INTRODUCTION}

Pandemic: A pandemic is defined as the "worldwide spread of a new disease." - World Health Organisation (WHO). When a new virus emerges first, there is a lack of natural immunity in most of us to tackle it. Which can cause a swift, occasionally rapid, blow-out of the infection betweenpublic, across populations, and

Biosc Biotech Res Comm P-ISSN: 0974-6455 E-ISSN: 2321-4007

\section{crossef}

Identifiers and Pagination

Year: 2021 Vol: 14 No (5) Special Issue Pages: 63-73

This is an open access article under Creative

Commons License Attribn 4.0 Intl (CC-BY).

DOI: $h t t p: / / d x$.doi.org/10.21786/bbrc/14.5/14
everywhereglobally.Deprived of a natural resistance to fight off asickness, many people can impact and turn out to be sick as it blow-outs.

Novel Coronavirus or Covid'19: According to WHO Coronaviruses $(\mathrm{CoV})$ are a large clan of viruses that cause infection ranging from the common cold to more chronicailments. A novel coronavirus ( $\mathrm{nCoV}$ ) is a new strain that has not been formerly identified in humans. The novel virus was consequently named the "COVID'19 virus”. Coronavirus (COVID'19) is acommunicable disease affected by a novel or newlyrevealed coronavirus.Most people disease-ridden with the COVID'19 virus will experience slight to moderate respirational illness and recover without necessitatingdistinctive treatment as found in SARS. Older persons, and those with history of underlying medical complications like chronic respiratory

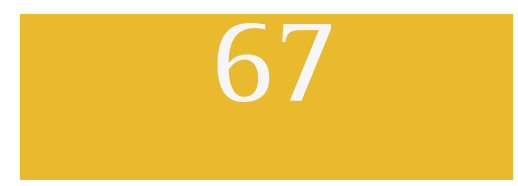


disease, diabetes, cardiovascular disease, and cancer are more likely to develop gravesickness.

Fisheries: "A fishery is an actionprominent to harvesting of fish. It comprise capture of wild fish or nurturing of fish through aquaculture." It similarly means "folksinvolved,technique of fishing, class of boats/ vessels/dinghies, species or type of fish, area of water or seabed, and purpose of the activities or anamalgamation of the foregoing attributes". - Food and Agriculture Organization (FAO) - United Nations

Pandemic and its impact of Fishers: COVID'19 Pandemic i.e. Novel Coronavirus Global Epidemic resulted in nearly shut down of overall business fraternity in both organised and unorganised segments globally. According to WHO Director Generals media briefing on 23rd February, 2020 it was concluded that no immediate relief for the disease was to be discovered and the medication which is generally provided with Severe acute respiratory syndrome (SARS) was the only alternative available. The governments all across globe had no other options than putting restrictions on movement of people. Gradually governments were forced for imposing complete lockdown in high density regions especially the urban and semi-urban regions.

As the business vis-à-vis logistics is symbiotic for remote villages / towns on urban infrastructure for all allied industries it also brought gradual business shutdown in villages and town. Furthermore certain cases were found in remote areas due to contact and connect of people from village to and fro cities, the casualties were increasing which compelledWorld Health Organisation (WHO), to give guidelines to governments to take immediate steps to stop the outbreak and declared it as Global Pandemic, hence Indian Government called for complete Lockdown of the nation on 24th March 2020. Guidelines wereissued accordingly from Ministry of Health and everything came to standstill.

People can't be locked up for a long period and hence essential services wereallowed to function with specific guidelines for functioning of organisations given from time to time. India being an agrarian economy the Ministry of Agriculture gave guidelines for production and movement of Food materials. Fishery is also a part of Ministry of Agriculture is very minuscule compared to Agro-based business network and infrastructure. As majorityArgo based business set-ups are still under private unorganised sector, The Fishery sector which comprises of widely artisanal and small scale occupational aboriginal communities those are furthermore disorganised.

The Lockdown imposed had stopped all the activities of Fishery related business due to very little clarity from government on Fishery business and supply chain. The Fishers started to face the heat of the same after some time. The impact of same was on income and overall livelihood on fishers as well as fishing allied ecosystem. The Fishing activities are mostly in Coastal places which have gradually developed into important logistical points of global trade due to presence of Fishing Docks and Jetties. The Salt on wound is these coastal places like Mumbai, Navi Mumbai, Sopara, Alibaug, Dahanu, Dapoli, Murud etc. are densely populated due to concentrated urbanisation. Resulting more number of COVID'19 cases in the surrounding regions.

The Maharashtra state government declared provisions under UNLOCK gradually opening up the industry, markets and other activities the business seems to be getting back to normal. This Normal is termed as new normal in organised industrial set-up as the daily routine, work life and social contact norms have changed drastically. This new normal is looking forward for changes in understanding for more sustainable livelihoods across occupations and businesses.

\section{Literature Review}

- Impact of COVID-19 on people's livelihoods, their health and our food systems (Joint statement by ILO, FAO, IFAD and WHO-ChriscadenKimberly, Communications Officer, World Health Organization, 13 October 2020) Thereport states the COVID'19 as a global epidemic has led to a histrionic loss of human life globally and presents an unique challenge to public health, the world of work and food systems. While the digit of malnourishedpeople, currently assessed at approximately6.9 crores, may rise by up to 1.32 crores by the year end. The socioeconomicdisturbanceproduced by the pandemic is shattering: Crores of people are at risk of sinking into punishing poverty, Lakhs of institutions and organisations face a threat of existence. Approximately half of the global labour force are at risk of mislaying their livelihoods. Unorganised economy employees are predominantlyhelpless because majority dearth social security and access to quality health care and have lost access to productive assets. With no means to earn an income during lockdowns, many are unable provide food to their families. For most, no earningsmeans no nutriment and more scare of getting infected easily.

- Economic Consequences of Coronavirus Disease (COVID-19) on Fisheries in the Eastern Mediterranean (Cyprus) (Giannakis Elias, HadjioannouLouis, Jimenez Carlos, Papageorgiou, MariosAnastasisKaronias and PetrouAntonis. Sustainability; Basel Vol. 12, Issue. 22, August 2020).Theiroutcomes areestablished on the questionnaire investigation that specifythe COVID'19 outbreak had very negative impact on fishermen's income. With 40\% and more fishermen and women stated that between mid of March and mid of May fishers were not been fishing due to social distancing constraints, while all of them stated a significant decline in their income. Severe negative effects were also reported for the fisheries sector of the Southeast Asian nations. On-line study for the commercial fishing trade in the North-eastern US shownalike disruptions for the sector.

- The Impacts of Covid-19 to Small Scale Fisheries in Tun Mustapha Park, Sabah, Malaysia; What do They Know So Far? (SakirunSarmalin, Payne Adam, 
JomitolJoannie, Mohd. Omar Bural WWF-Malaysia, May, 2020). They studied that plummeting demand for fish and the selling prices along the supply chain, which is beyond the fishers' control, have restricted their purchasing and resulted in potential loss of income earning opportunities. Post Covid-19 rapid study should be conducted to obtain a quick understanding of the food security and livelihood situation of all fishing communities.

- Assessing Impacts of COVID-19 on Aquatic Food System and Small-Scale Fisheries in Bangladesh (Sharif Ahmed Sazzad,AtiqurRahman Sunny, Sarker, Ashoke Kumar,Ashrafuzzaman, Datta, Gopal Chandra, Preprints; Basel, June 2020.) The paper states that the pan epidemic known as COVID'19 has had a disastrouseffects on human activities, with aquatic food sector i.e. small-scale fishers being no exclusion. Food demand and thus food security are rigorously compromised due to movement restrictions, reduced buyers and further impact on the most susceptible small-scale fisheries and concomitantcommunities or business. Therefore, any actproceeded by the Administrationor Government must be based on shielding the health and food security of the people particularly to the marginalised classes, while it could be unfavourable to economic growth in the short run.

- Effect of COVID-19 on Economy in India: Some Reflections for Policy and Programme (Das Shankar, Chaudhary Monika, Sodani.P. R. - Journal of Health Management, August, 2020).Thearticle states that the growth and prevalent COVID'19 pan epidemic has disturbed the thriving economy globally in impulsive and uncertain terms. The presentrecession seems primarily diverse from recessions in the past which had shaken the economic order of the country. However the nations, corporations, establishments and international business continue to understand the magnitude of the pan epidemic, it is unquestionably the need of the hour to formulate for a future that is m more sustainable, fundamental and structurally more feasible for existence and functioning. The COVID'19 global epidemic have given a clear message for the growing Indian economy must adopt more sustainable progressive models, which are based on more inclusive frameworks, self-reliance, and are based on eco-friendly approaches.

- Impact of COVID-19 Lockdown on the Fisheries Sector: A Case Study from Three Harbors in Theystern India (Singh Deepak, Ali P. Yunus,MisraPrakhar, TonniAgustionoKurniawan, AvtarRam, Desai Pranav N., KouserAsma, DehaAgusUmarhadi, and KBVN PhanindraRemote Sensing; Basel Vol. 13, Issue. January, 2021).Their study reveals that the fisheries activity in India was severely affected during the state of nationwide lockdown. The COVID'19 specific lockdown have left fisheries workers stranded from sailing and operational tasks. By monitoring the temporal changes in the area covered under the ships during prior-lockdown, lockdown, and afterlockdown phases in the study area using highresolution PlanetScope imagery, they shot the utility of remote sensing technology as a tool for tracking COVID impacts in the fisheries sector.

\section{Objectives of Research}

- Study the impact of Covid'19 Pandemic on Fisheries

- Understand perspective of Fishers community on Pandemic persuaded Lockdown.

- Understand impact of lockdown on Income and livelihood of Fisher Community

- Understand post lockdown scenario of Fishery sector.

\section{RESEARCH METHODOLOGY}

The research paper is purely exploratory and descriptive based on primary data collected by interviewing fish farmers, fish sellers, \& fishery related allied business persons (focus group) from fishing communities in various coastal places of Maharashtra and Secondary sources from national and international websites, reports, circulars, journals etc.

\subsection{Data Collection}

The Primary Data is duly collected by interviewing and discussing with the member representatives of Fisher Community. Secondary Data is used as a base to understand fishery sector from various Governmental and Non-Governmental Publications online and offline.

\subsection{Analysis of Data \\ 4.2.1 Demographic data of people interviewed.}

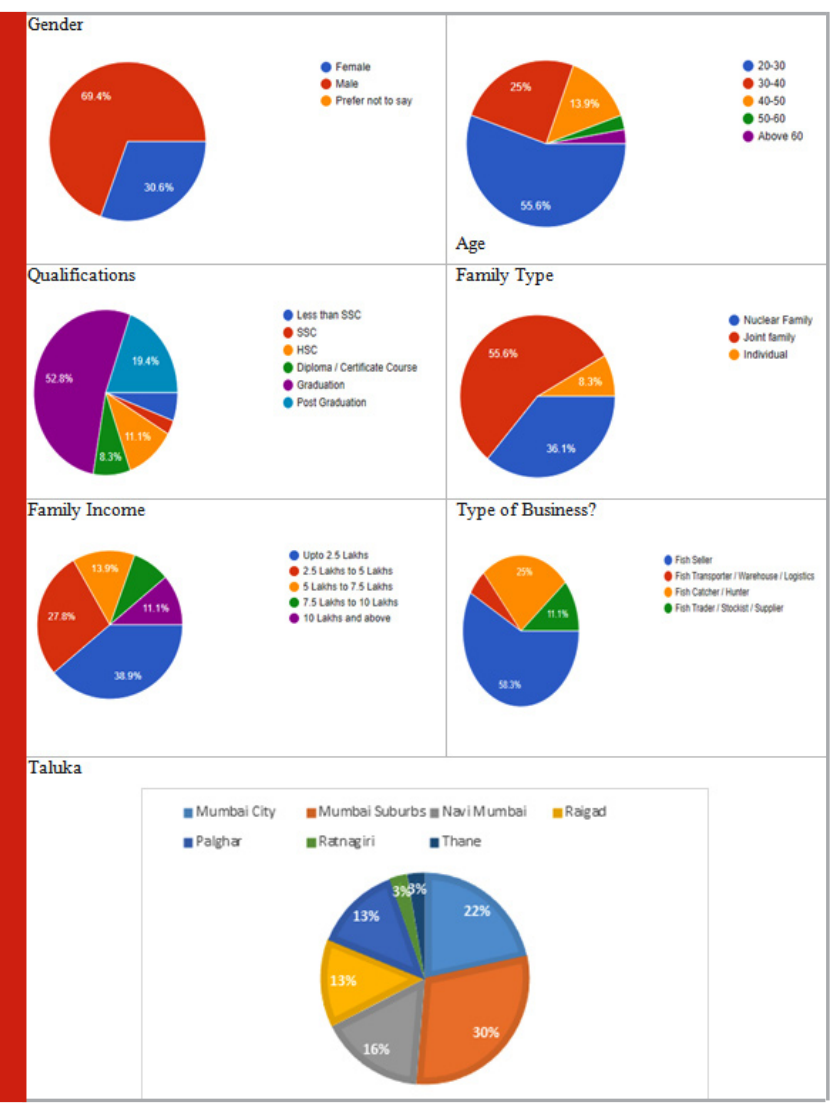


Do you believe in reports of COVID'19 which is spread from Wuhan South China Seafood Wholesale Market was because of consuming Fish during Lockdown?

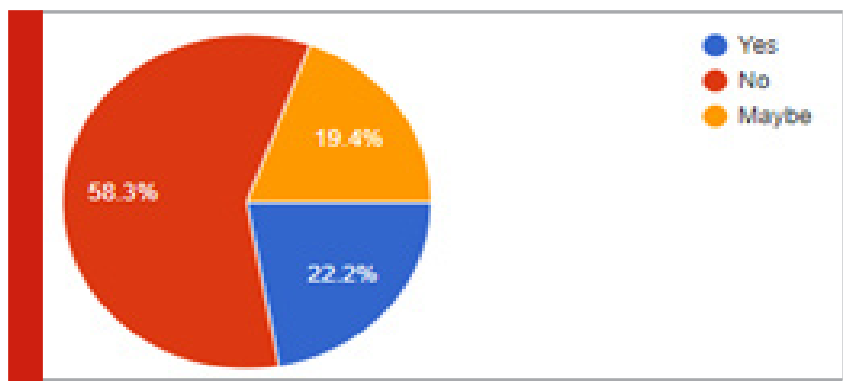

\subsubsection{Impact during Lockdown}

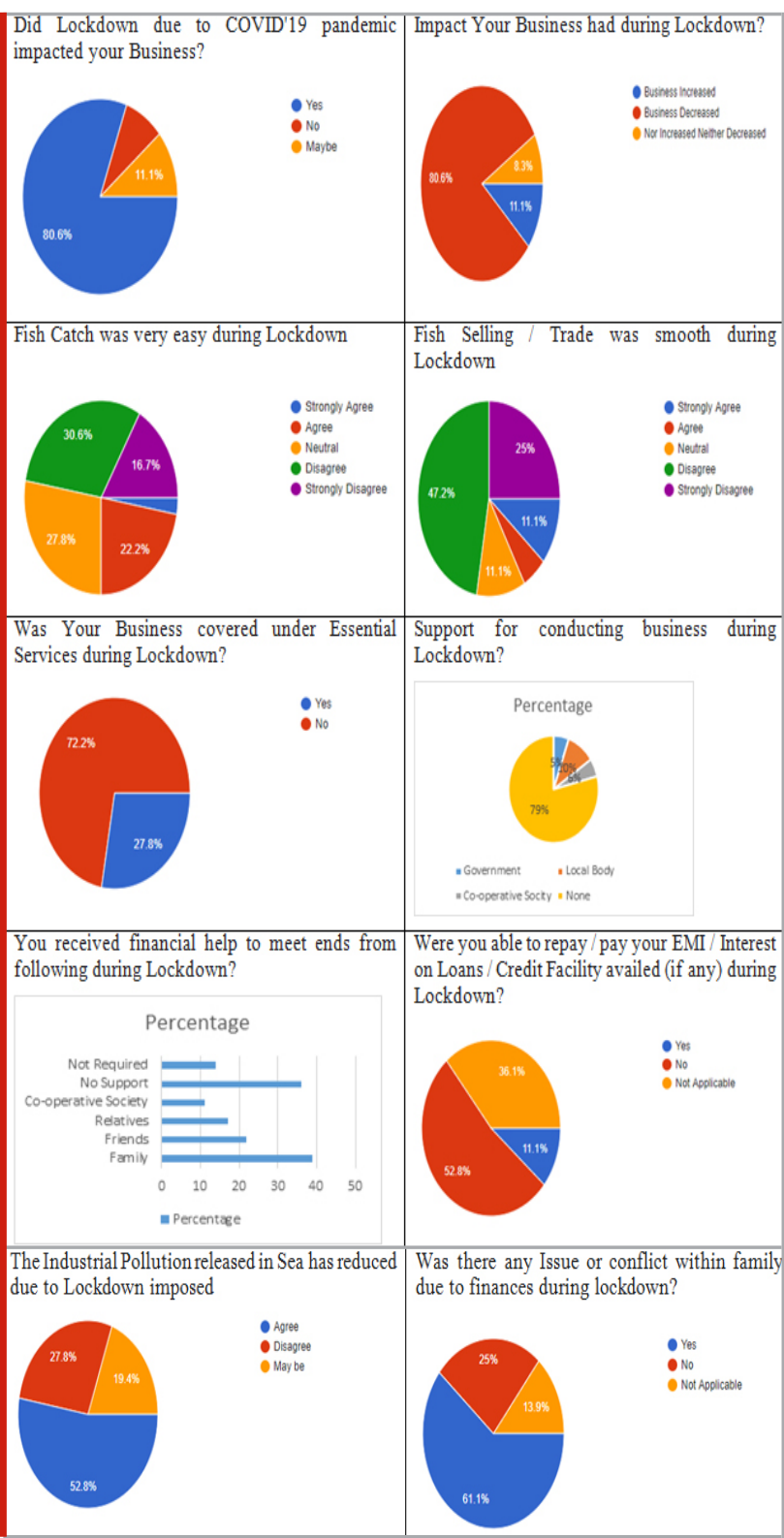

Is it safe to eat Fish now as things are becoming normal?

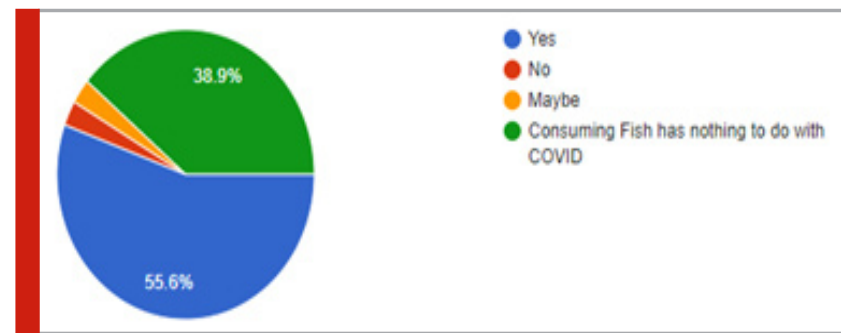

\subsubsection{Impact after Lockdown}

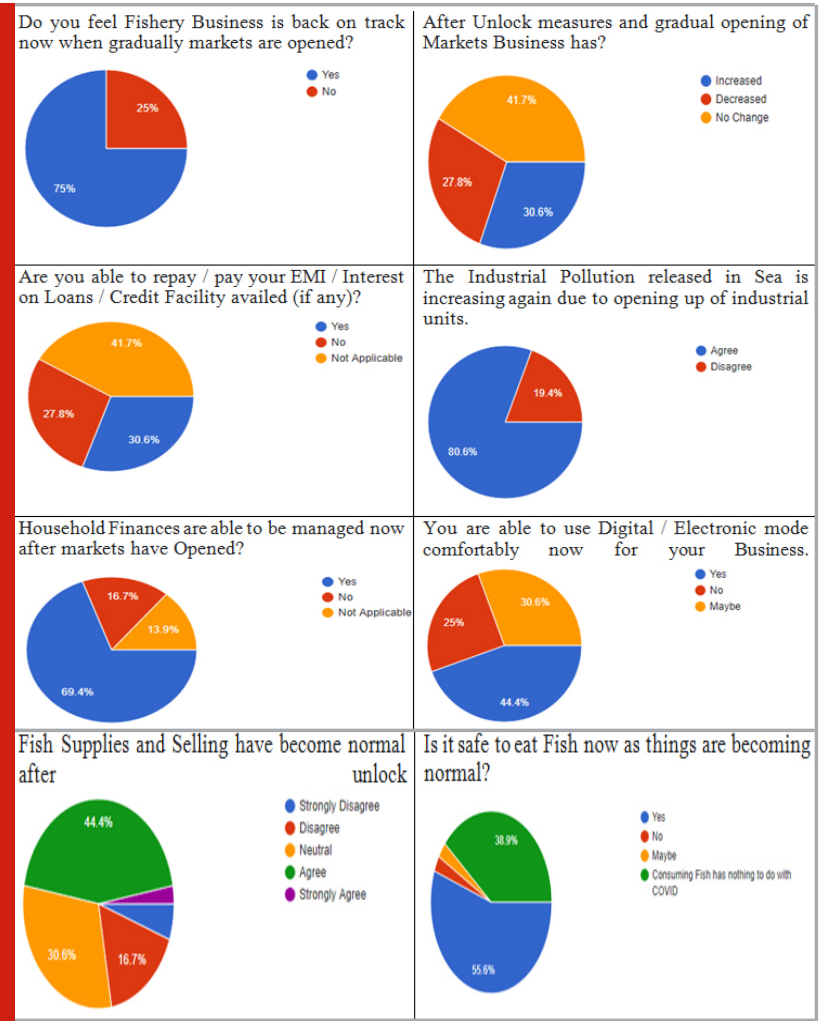

\subsubsection{The Way Forward}

Government should play more vital role in supporting Fishery Business as Sustainable Livelihood and Entrepreneurship may be guaranteed as other business collapsed during Lockdown for making

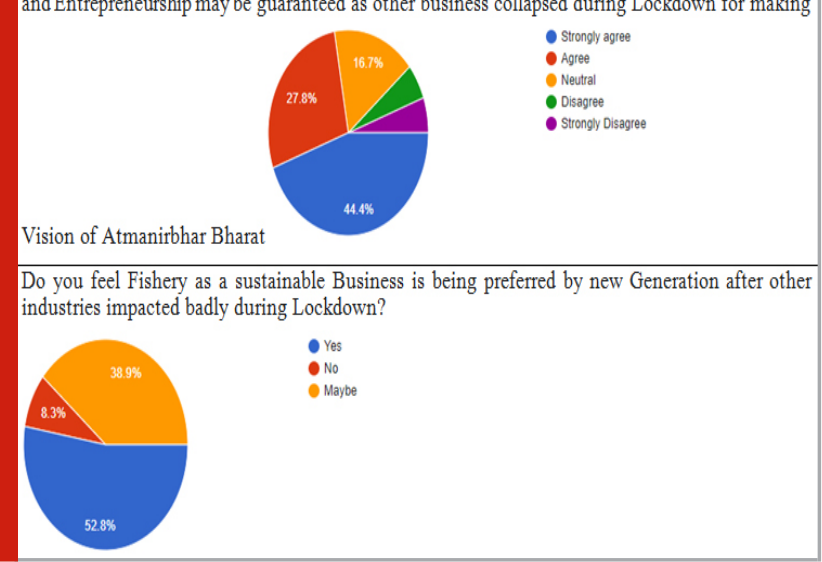

\subsubsection{Issues Faced during Lockdown}

- Low Sales as people were not coming out and also wrong perception on Fish consumption was being promoted by some unknown sources.

- No Fish Catch Allowed as security forces / police were not allowing for sailing. 
- Transportation, Ice Factories, and overall Logistics was stopped due to no clarity to police or security officials on whether Fish and Fishery are under essential services.

- Exports was totally stopped due to closure of all international activities.

- When lockdown was suddenly declared Tons of fish had to be thrown back into the sea, incurring heavy losses.

- No any package or support declared by government and wherever it was granted it didn't reach the community people.

- Farmers are given so many subsidiaries as well as funds under numerous schemes by the Government, then why no attention is given to one of the oldest community based artisanal fishers residing at coasts

- In guise of lockdown many infrastructure projects were started in sea or near coasts.

\subsubsection{Positive impact of Lockdown}

- The sewage and other pollutants released in sea reduced resulting in less pollution near coasts.

- Fish breeding and quantum of fishes increased due to less pollution and no fishing.

- Online mode of fish selling was learnt.

- Majority says nothing is positive seen yet.

\subsubsection{Issues faced after government declared Unlock and} gradual opening of markets and economy.

- Fish rates tumbled as delusion and false narrative of relating fish with COVID impacted sales.

- Societies and certain markets not allowing fish selling

- Transportation getting affected as faresare hiked, and limited train travel timings.

- Unsustainable and disturbing infrastructure projects like Coastal Road, Industrialisation, Port Trust Activities, Docks, Sea Bridge, ONGC rigs, Construction activities, etc. were given more boost during lockdown which is in process impacting fish catch in shallow waters.

- Pollution increasing gradually

- Oil leakage and Warm water released by heavy Mercantile Ocean liners, Cargo ships etc.

- Financial problems due to unorganised sector finance service providers badly hit by COVID.

- Many non-fishers have entered the business impacting the coastal communities business.

4.2.8 Positive impact after government declared Unlock and gradual opening of markets and economy.

- Small scale business increased

- Fuel prices increased impacting price

- Educated younger generation viewing fishing as a long term and sustainable occupation and an alternative to unstable derived industry.

- But majority people still don't see the positive yet due to overall business and economy downfall.

4.2.9. Fishers Comments/Suggestions on impact of COVID'19 and normal world after that for Fishers

\section{Business.}

- Fish market not working properly and fisherwoman have to face many hardships

- Government Schemes and information is not reaching to poor fisherman \&t women as many are still not understanding Fisheries is also a food commodity and are covered in essential commodities.

- Fisheries needs crucial attention from Legislation and Administration just like Agriculture.

- Government should take measures by playing vital role by providing subsidies,aids,moratorium for low income and unorganised yet process oriented set up like fisheries.

- Increasing pollution in Sea and Oceans due to Oil Rigs, Merchant Transports etc.

- Increasing pollution in Sea and Oceans due to massive construction proposed or starter near or on coasts like Sagarmala, Blue Economy, Coastal Roads etc.

- Government should also pay attention to the fishing community as they do for other businesses and provide good schemes along with funds as they need it for the raw material which is required for fishing i.e. big ice boxes, diesel, Gas cylinder, etc. for which they need to lend funds from banks or cooperative credit societies.

- Whereas, if government would provide them funds with low interest or by any scheme. It will really help this community.

- More Institute/ colleges for fish processing and ocean study and also on marketing, logistics, warehousing, management, etc. concerning fisheries industry.

\section{FINDINGS AND CONCLUSION OF THE STUDY}

Fishing business just like any other occupation in India is still a community/tribe based business affair. The fishermen are still artisanal and traditional with little fraction moving towards mechanised or trawler based fishing. The fishing as an business is still neglected and seen as a outcaste by predominant agrarian perceived society of India and hence based on historical inferences drawn it's also deprived and neglected by mainstream, hence community is listed as schedule tribe / backward classes based on various social studies carried. The overall fishing activity is unorganised and very few are associated with Co-operative societies whose role is still very retrograde. Due to such prevailing conditions the COVID pandemic induced lockdown further created a problem for fishers whose life is generally hand to mouth. The hardships and problems were increased where fish catch, fish logistics and fish sales were totally shut.

Entire Fishery related ecosystem collapsed making the concern of life and survival for fishers. Fishing is one of the essential food commodities based on its nutrient value is still not been fully convinced by mainly vegetarian Indian society. In 21st century also fishery is highly perishable compared to agriculture produce or livestock business due to absence of infrastructure for storing, distribution network and processing. The gradual opening after unlock measures for economy and 
markets saw high fish catch and low sales resulting to further losses as storing and processing was big concern. The increasing pollution in seas, oil spillage by cargo vessels, and permission for coastal road during lockdown where construction started in full swing added more complications for fishers. The climate change, uneven rain, cyclones etc. are further environmental disasters which have impacted the type of fish catch and overall fishing activities.

Post Lockdown unlike previous generation, literate younger/new generation considers fishery as serious occupation activity if certain provisions made can provide alternate sustainable livelihood and second income when compared with other business ecosystem which collapsed fully during lockdown. Fishers feel they are directly dependent on nature and environment and hence climate change and global warming should be taken seriously and mechanisms to be drawn to save the coasts for further scope of business. The fishers are looking at array of hope wherein government takes fishing as a serious business activity and sanctions more budget for its development which is holistic as well as sustainable.

\section{Limitations of the Research}

- The samples for research are geographically limited to the Coastal Districts of Maharashtra; hence the sample may not be an ideal representation of the Issue.

- The information is purely based on knowledge and understanding of the convenience sample chosen for the research due to time and mobility constraints due to COVID pandemic.

- Since most of the data collected is primary, similar data might not be available from any other source for cross-checking.

Bibliography \& References: Personal Interview with Active Fishermen, Fish Sellers, Fish traders and Fishery Co-operative Society members from Fishing Community representing Ratnagiri, Raigad, Navi Mumbai, Thane, Mumbai City, Mumbai Suburban and Palghar districts of Maharashtra State in India.

\section{REFERENCES}

TarikJasarevic, Christian Lindmeier and FadelaChaib (2020). Statement on the furst meeting of the International Health Regulations (2005) Emergency Committee regarding the outbreak of novel coronavirus (2019nCoV). [Online] Available At: https://www.who.int/ news/item/23-01-2020-statement-on-the-meetingof-the-international-health-regulations-(2005)emergency-committee-regarding-the-outbreak-ofnovel-coronavirus-(2019-ncov) [Accessed 20th Feb, 2021]

AmeyTirodkar (2021). Maharashtra: Lockdown Scare Hurting Fishermen More Than Corona's Return. Newsclick [Online] Available at: https://www.newsclick.
in/Maharashtra-Lockdown-Scare-Hurting-FishermenCorona-Return [Accessed 25th Feb, 2021]

Elias Giannakis, Louis Hadjioannou, Carlos Jimenez, MariosPapageorgiouAnastasisKaronias and AntonisPetrou (2020). Economic Consequences of Coronavirus Disease (COVID-19) on Fisheries in the Eastern Mediterranean, Cyprus Sustainability; Vol. 12, Issue. 22

HimanshuNitnaware (2020). How a bunch of Mumbai's fishers kept their businesses afloat amid coronavirus lockdown. [Online] Available At: https://scroll.in/ article/964307/how-a-bunch-of-mumbais-fishers-kepttheir-businesses-afloat-amid-coronavirus-lockdown [Accessed 25th Feb, 2021]

JoannieJomitol, Adam J. Payne ,SarmalinSakirun , Mohd. Omar Bural (2020) The Impacts of COVID-19 to Small Scale Fisheries in Tun Mustapha Park, Sabah, Malaysia; What Do We Know So Far? Sabah, Malaysia. Preprints.

Joint statement by ILO, FAO, IFAD and WHO - 'Kimberly Chriscaden', 'Communications Officer, World Health Organization' (2020). Impact of COVID-19 on people's livelihoods, their health and our food systems, , Geneva, WHO [Online] Available At: https://www. who.int/news/item/13-10-2020-impact-of-covid-19on-people's-livelihoods-their-health-and-our-foodsystems [Accessed 20th Feb, 2021]

Nathan Fulgado. (2020). Mumbai's fishermen in crisis. The Free Press Journal, [Online] Available At: https:// www.freepressjournal.in/mumbai/mumbais-fishermenin-crisis [Accessed 26th Feb, 2021]

Ram Avtar, Deepak Singh, DehaAgusUmarhadi, Ali P. Yunus, PrakharMisra, Pranav N. Desai, AsmaKouser, TonniAgustionoKurniawan and KBVN Phanindra (2021). Impact of COVID-19 Lockdown on the Fisheries Sector: A Case Study from Three Harbors in Western India. Remote Sensing for Environment and Disaster, pp. 183

SanjanaBhalerao. (2021). Business hit by pandemic: Fishermen count losses as funds crunch keeps boats grounded. Mumbai. The Indian Express [Online] Available At: https://indianexpress.com/article/ cities/mumbai/business-hit-by-pandemic-fishermencount-losses-as-funds-crunch-keeps-boats-grounded7197461/ [Accessed 25th Feb, 2021]

Saurabh Gupta [2020]. How Mumbai's Oldest Community Is Coping Amid The COVID-19 Lockdown. NDTV [Online] Available at: https://www.ndtv.com/ mumbai-news/coronavirus-lockdown-how-mumbaisoldest-community-koli-community-is-coping-amidthe-covid-19-lockdow-2203022 [Accessed 20th Feb, 2021] 
Shankar Das, Monika Chaudhary, and P. R. Sodani. (2020). Effect of COVID-19 on Economy in India: Some Reflections for Policy and Programme, India, Journal of Health Management.

Sharif Ahmed Sazzad, AtiqurRahman Sunny, Sarker, Ashoke Kumar, Ashrafuzzaman, Datta, and Gopal Chandra. (2020). Assessing Impacts of COVID-19 on Aquatic Food System and Small-Scale Fisheries in
Bangladesh, Basel, Preprints.

WHO Media (2020). A Joint Statement on Tourism and COVID-19 - UNWTO and WHO Call for Responsibility and Coordination. [Online] Available At: https://www. who.int/news/item/27-02-2020-a-joint-statement-ontourism-and-covid-19---unwto-and-who-call-forresponsibility-and-coordination [Accessed 20th Feb, 2021] 